\title{
Gender Differences in Axial Spondyloarthritis: Women Are Not So Lucky
}

\author{
T. Rusman $^{1}$ - R. F. van Vollenhoven ${ }^{1}$ - I. E. van der Horst-Bruinsma ${ }^{1}$ \\ Published online: 12 May 2018 \\ (C) The Author(s) 2018
}

\begin{abstract}
Purpose of Review Ankylosing spondylitis (AS) was historically seen as a predominantly male disease. However, more recent data showed a more homogenous sex prevalence. Unfortunately, in many studies in axial spondyloarthritis (axSpA), the number of women included is low and the analyses are often not stratified for gender distribution. The purpose of this review is to aggregate the existing data on gender differences in axSpA in order to increase the awareness that female axSpA patients are still under-recognized.

Recent Findings Several studies considering gender differences revealed that female axSpA patients had different disease manifestations due to different immunological, hormonal, and genetic responses. For instance, allelic frequencies of the AHNK-gene and tissue non-specific alkaline phosphatase (TNAP) haplotypes differed between men and women with ankylosing spondylitis (AS). In addition, different levels of tumor necrosis factor (TNF), interleukins IL-6, IL-17, and IL-18, were found between the two sexes. Furthermore, female patients show a higher diagnostic delay compared to males. Several studies indicate a higher frequency of extra-articular manifestations (EAM) in female axSpA patients, such as enthesitis, psoriasis, and inflammatory bowel disease (IBD), whereas acute anterior uveitis is more prevalent in male patients. Male AS patients more frequently show a higher Bath Ankylosing Spondylitis Radiology Index (BASRI) scores and modified Stoke Ankylosing Spondylitis Spine Scores (mSASSS) than females, which indicates that males have higher radiological damage and radiographic progression. However, disease activity (BASDAI) and quality of life (AsQol) scores are significantly higher in women, and more importantly, they have significantly lower response rates to treatment with TNF inhibitors (TNFi) and a significantly lower drug adherence. Summary Despite the fact that men with axial SpA have a worse radiologic prognosis, women have a high disease burden, in part because they have a longer delay in diagnosis, higher disease activity, and significantly less responsiveness to treatment with TNFi.
\end{abstract}

Keywords Axial spondyloarthritis $\cdot$ Gender $\cdot$ Sex $\cdot$ Disease manifestation $\cdot$ TNF inhibitors $\cdot$ Radiological progression

\section{Introduction}

There is increasing evidence that in drug development, any potential sex and gender differences in general have not been addressed sufficiently, and sometimes never addressed at all $[1 \bullet \cdot, 2]$. For example, in vitro experiments are performed in cell lines with unknown $\mathrm{XX} / \mathrm{XY}$ karyotype, animal experiments are only performed in male mice (in order to prevent "hormonal disturbances"), women are underrepresented in

This article is part of the Topical Collection on Spondyloarthritis

I. E. van der Horst-Bruinsma

ie.vanderhorst@vumc.nl

1 Amsterdam Rheumatology and Immunology Center, Amsterdam, The Netherlands phase 1 and 2 trials (despite significant differences in pharmacodynamics and pharmacokinetics between men and women), phase 3 trials are not powered to detect gender differences in efficacy or toxicity, and post-marketing studies are not always analyzed after stratification for sex $[1 \bullet \cdot, 2]$. Recently, sex and gender differences in several diseases are being recognized, such as clinical presentation of cardiovascular disease [3].

First, the terms sex and gender, which are often used interchangeably, need clarification. The term "sex differences" is used to describe differences in biological processes between males and females, such as hormonal, genetic, and immunological functions in a disease. The term gender can be used for describing a person's self-perception as male or female, and behavioral expression (such as coping style and disease perception) [4]. Thus, besides cardiovascular diseases, gender differences in disease manifestations have also been described in rheumatic diseases, including spondyloarthritis $(\mathrm{SpA})$. 
$\mathrm{SpA}$ is a chronic inflammatory rheumatic disease that can be divided into predominantly axial and predominantly peripheral forms [5]. Axial SpA (axSpA) encompasses ankylosing spondylitis (AS) with radiological signs of sacroiliitis, and a type without radiographic sacroiliitis, initially called "spondylitic disease without radiographic sacroiliitis" [6] and now renamed "non-radiographic axial SpA" or nraxSpA [5, 7]. Nr-axSpA might progress to AS within several years $[5,8,9]$. Historically, the male-female prevalence ratio showed a large overestimation favoring males, especially among AS patients; for example, initial studies showed a male-female ratio of 10:1 [10-12]. Subsequently, this ratio has been reported to be approximately 3:1 [13-19]. The most current study reports a steady decline in the male-female ratio among patients with AS/axSpA in Switzerland from 2.57:1 in 1980, down to $1.03: 1$ by the end of 2016 [20]. In contrast to AS, nr-axSpA patients show hardly any difference in its prevalence among males and females [5, 21-23].

Characteristic symptoms of SpA are inflammatory back pain and progressive functional limitations. In addition, extra-articular manifestations (EAM's) can develop, such as anterior uveitis (30-40\%), psoriasis (10\%), and inflammatory bowel disease (IBD, 5-10\%) [24]. Since the introduction of TNF alpha inhibitors (TNFi), the treatment of axSpA has improved dramatically [25]. Although the large benefits of this treatment for many axSpA patients, currently, several studies show gender and sex differences in treatment response and adherence and in several other aspects of axSpA, such as disease manifestations and disease burden [23, 26••, 27-33].

Despite accumulating study results considering gender and sex differences in axSpA, female patients are still underrepresented in clinical research $[1 \bullet \bullet$. This under-recognition results in delay in diagnosis, which causes under-diagnosis and delay of optimal treatment strategies, which leads to increased disease burden in female axSpA patients.

The aim of this review is to aggregate the existing data on gender and sex differences in axSpA, in order to increase the awareness of female axial SpA patients, since there is still under-recognition.

\section{Immunology and Genetics}

Immunological and genetic data showed clear sex dimorphisms in response and expression (Table 1). Recent publications revealed a sex difference in immune response of the cytokine TNF $\alpha$ and the interleukin Il-17A. Male axSpA patients showed significant elevated levels of TNF $\alpha$ and Il-17A compared to female patients [34•]. In addition, in AS patients with syndesmophytes, men had significantly higher IL-18 levels, whereas women showed significantly elevated IL-6 [35]. Moreover, sex differences were also found in gene expression in AS patients. One study identified a sex-specific gene expression profile, showing 291 genes uniquely expressed in female AS patients, 1522 genes expressed in males with AS, and 650 genes expressed in both male and female AS patients compared with healthy matched controls [34-]. Another study revealed that different loci of the ANKH gene were associated with AS in male versus female patient [37]. The ANKH gene encodes a progressive ankylosing protein, which is involved in the structural damage in axSpA patients. Moreover, sex differences were found in TNAP (tissue-nonspecific alkaline phosphatase) haplotype, which interplay with the ANKH gene in ossification. This specific TNAP haplotype was associated with AS in men, but not with women with AS [36].

In addition, sex hormones might also play a role. Estrogen has an anti-inflammatory effect on SpA manifestations by inhibiting TNF alpha production, although contradicting results were presented [2]. One older study revealed a decrease in arthritis and clinical activity in 17 female AS patients after oral estrogen therapy [42]. They also demonstrated that in premenopausal female patients with active AS, the estrogen levels were lower compared to females with inactive disease and significantly lower compared to controls. Also, in postmenopausal AS patients, estrogen levels were lower compared to controls. However, a more recent study showed neither difference in onset nor severity in 571 female AS patients, of which 448 women had used oral estrogen therapy and 123 did not [39]. In a study with a mouse model, the female mice with high estrogen levels had significantly less severe arthritis and SpA manifestations (such as spondylitis, enthesitis, and bowel inflammation) compared to mice with low estrogen levels [38]. In a review and casecontrol study of 50 males and 10 female AS patients, Giltay et al. [42] described that serum testosterone levels were not elevated in AS patients compared to controls and did not seem to influence progression of AS [41]. However, the precursor of both testosterone and estradiol, dehydroepiandrosterone (DHEAS), which enhances the Th1 immune response, might play a role in the onset and severity of the AS (Table 1). Furthermore, the review revealed that the role of sex steroids in the pathogenesis of AS needs further investigation $[41,43]$.

These results considering sex differences in immune response, genetic associations and sex hormones, show biological mechanisms, which might contribute to different disease manifestations, disease perception, and treatment response in men and women with axSpA.

\section{Delay in Diagnosis}

The age of onset of AS does not differ between males and females [44, 45], but female seem to have a relatively longer delay in diagnosis (Table 2). For example, this delay in 1976 
Table 1 Sex differences in immunological, hormonal, and genetic aspects in Axial SpA

\begin{tabular}{|c|c|c|c|c|}
\hline Author & AS or axSpA & Study design & $\mathrm{M} / \mathrm{F}$ & Observations \\
\hline \multicolumn{5}{|c|}{ Immunological markers } \\
\hline Gracey, $2016[34 \bullet]$ & AS & Observational Cohort & $53 / 41$ & $\begin{array}{l}\uparrow \text { IL-17A levels + TH17 cells only in male AS patients* } \\
\uparrow \text { TNF levels in only male AS patients* }\end{array}$ \\
\hline Huang, 2012 [35] & AS & Cross-sectional & $68 / 19$ & $\begin{array}{l}\uparrow \text { IL-18 levels in only male AS patients* } \\
\uparrow \text { TNF levels only in male AS patients* } \\
\uparrow \text { IL-6 levels in only female AS patients* }\end{array}$ \\
\hline \multicolumn{5}{|l|}{ Genetic markers } \\
\hline Tsui, 2007 [36] & AS & Cross-sectional & & $\begin{array}{l}\text { TNAP haplotype rs3767155 (G)/rs3738099 (G)/ rs1780329 (T) } \\
\text { is a genetic marker associated with AS only in men* }\end{array}$ \\
\hline Tsui, 2005 [37] & AS & Cross-sectional & & $\begin{array}{l}\text { ANKH genetic markers at } 5^{\prime} \text { end of the gene are associated with } \\
\text { AS in affected women; haplotype: rs } 28006[\mathrm{C}] \text { and rs } 25957[\mathrm{C}]^{*} \\
\text { ANKH genetic markers at the } 3^{\prime} \text { end of the gene are associated } \\
\text { with AS in affected men; haplotype: rs } 26307[\mathrm{C}] \text { and rs } 27356[\mathrm{C}]^{*}\end{array}$ \\
\hline \multicolumn{5}{|l|}{ Sex steroids } \\
\hline Jeong, $2017[38]$ & $\operatorname{axSpA}$ & Experimental & $\begin{array}{l}\text { Female mouse } \\
\text { models }\end{array}$ & $\uparrow$ estrogen levels suppressed arthritis in female SKG mice (SpA model)* \\
\hline $\begin{array}{l}\text { Mahendira, } 2014 \\
\text { [39] }\end{array}$ & AS & Cross-sectional & $0 / 571$ & $\begin{array}{l}\text { Exogenous estrogens are not associated with initiation or severity of } \\
\text { AS in women }\end{array}$ \\
\hline Aydin, 2005 [40] & AS & Cross-sectional & $58 / 0$ & $\begin{array}{l}\text { Possible relation between low dehydroepiandrosterone (DHEAS) and } \\
\text { bone loss in male AS patients }\end{array}$ \\
\hline Giltay, 1998 [41] & AS & Case-control & $50 / 10$ & $\begin{array}{l}\text { Serum testosterone levels are not elevated in male AS patients } \\
\text { Other sex steroids differ not between patients and controls }\end{array}$ \\
\hline $\begin{array}{l}\text { Jimenez-Balderas, } \\
1990[42]\end{array}$ & AS & Case-control & $0 / 17$ & $\begin{array}{l}\text { Exogenous estrogen levels suppressed arthritis and lower clinical } \\
\text { disease activity }\end{array}$ \\
\hline
\end{tabular}

$M$ male; $F$ female; $A S$ ankylosing spondylitis; $a x S p A$ axial spondyloarthritis; $S p A$ spondyloarthritis; $I L-6$ interleukin 6 , pro-inflammatory cytokine; $I L$ $17 A$ interleukin 17, pro-inflammatory cytokine; $I L-18$ interleukin 18, pro-inflammatory cytokine; TH17 cells T-helper 17 cells; TNF tumor necrosis factor; TNAP tissue non-specific alkaline phosphatase; ANKH gene progressive ankyloses protein

*Significant gender/sex differences

was reported to be approximately 10 years in female versus 3 years in male patients [13]. Later observations showed a median delay of 9 to 14 years in female and 5 to 7 in male patients [18]. A recent meta-analysis covering a total of 42 studies including 23,889 patients (32.3\% women) showed a significantly longer delay in diagnosis among female patients compared to males, 8.8 versus 6.5 years, respectively, with a significant overall effect of all included studies of approximately 0.6 years $(p<0.0001 ; 95 \%$ CI $0.31-0.89)$ [58•]. Only one study revealed a higher diagnostic delay in males compared to females, 9.9 and 6.3 years, respectively [47]. Incidentally, among AS patients as a whole, the median delay in diagnosis is significantly longer in HLA-B27-negative patients (11.4 years) than among those who possess this gene (8.5 years) [45].

Several reasons have been described to explain the longer diagnostic delay among females, such as the known differences in the presenting clinical symptoms reported by female patients, such as a lower frequency of typical inflammatory back pain as one of the presenting manifestation, more prominent upper thoracic and neck or wide spread pain, along with less severe or slower progression of radiographic damage [53]. Female patients who report wide spread pain are twice as likely to have a delayed diagnosis compared to those without this symptom [53]. The group with wide spread pain was frequently misdiagnosed with fibromyalgia, since it has some overlapping symptoms with axSpA [59]. Almost $25 \%$ of female axSpA patients were misdiagnosed at first, although both male and female patients had nonspecific low back pain as pre-SpA diagnosis. This could be the result of physicians' bias that axSpA is mostly a male disease, and their lack of knowledge of the different disease manifestation in female patients [53].

In conclusion, despite the improvement in delay of diagnosis in women with axSpA, there is still a longer delay and more often misdiagnosis in women, which increase the disease burden in the female patient group.

\section{Extra-Articular Manifestations}

Female gender was found to be positively associated with several extra-articular manifestations (EAM) $[60,61]$ (Table 3), but others found no differences [50, 53, 68]. Conflicting results have also been reported regarding gender differences in occurrence of acute anterior uveitis (AAU), the 
Table 2 Gender differences in diagnostic delay of axial $\mathrm{SpA}$

\begin{tabular}{|c|c|c|c|c|}
\hline Study & AS or axSpA & Study design & $\mathrm{M} / \mathrm{F}$ & $\begin{array}{l}\text { Delay in diagnosis } \\
\text { (years) } \mathrm{M} / \mathrm{F}\end{array}$ \\
\hline Mogard, 2017 [46] & axSpA & Cross-sectional & $128 / 55$ & $\begin{array}{l}\text { AS } 7.6 / 8.6 \\
\text { USpA } 6.7 / 6.1\end{array}$ \\
\hline Bandinelli, 2016 [47] & AS & Retrospective & $91 / 44$ & $9.9 / 6.3^{*}$ \\
\hline Webers, $2016[48 \bullet]$ & $\mathrm{AS}$ & Prospective observational cohort & $154 / 62$ & $8.0 / 10.8^{*}$ \\
\hline Landi, 2016 [49] & AS & Observational cohort & $817 / 255$ & $8.9 / 7.8$ \\
\hline Shahlaee, 2015 [50] & AS & Prospective cohort & $253 / 67$ & $8.0 / 8.8$ \\
\hline Bodur, 2012 [51] & AS & Prospective observational cohort & $1038 / 343$ & $4.9 / 5.3$ \\
\hline Yacoub, 2012 [52] & AS & Cross-sectional & $87 / 43$ & $4.6 / 4.8$ \\
\hline Slobodin, 2011 [53] & axSpA & Cross-sectional & $79 / 72$ & $5.9 / 5.7$ \\
\hline Roussou, 2011 [54] & axSpA & Prospective cohort & $150 / 293$ & $5.6 / 6.3$ \\
\hline Atagunduz, 2010 [55] & AS & Cross-sectional & $139 / 96$ & $6.2 / 7.4$ \\
\hline Dincer, 2008 [56] & AS & Cross-sectional & $103 / 8$ & $5.3 / 14.4$ \\
\hline Reed, 2008 [57] & AS & Cross-sectional & $91 / 35$ & $7.3 / 10.2$ \\
\hline
\end{tabular}

Diagnostic delay: first manifestation of the disease symptoms until time of diagnosis

$F$ female, $M$ male, $A S$ ankylosing spondylitis, axSpA axial spondyloarthritis, USpA undifferentiated SpA

*Significant gender/sex differences most common EAM. It seems to occur more commonly among male patients $[48 \cdot, 65,67]$, but a systematic literature review reported occurrence of AAU to be $28.5 \%$ in males versus $33.3 \%$ among females [69]. However, this study made no distinction between different types of uveitis, which is important because intermediate and posterior uveitis are unusual

Table 3 Sex differences in extra-articular manifestations in axial SpA

\begin{tabular}{|c|c|c|c|c|c|c|c|}
\hline Study & AS or axSpA & Study design & $\mathrm{M} / \mathrm{F}$ & $\begin{array}{l}\text { Anterior Uveitis } \\
\mathrm{M} / \mathrm{F}\end{array}$ & $\begin{array}{l}\text { Enthesitis } \\
\mathrm{M} / \mathrm{F}\end{array}$ & $\begin{array}{l}\mathrm{IBD} \\
\mathrm{M} / \mathrm{F}\end{array}$ & $\begin{array}{l}\text { Psoriasis } \\
\mathrm{M} / \mathrm{F}\end{array}$ \\
\hline Ibanez, 2017 [62••] & AS & Prospective cohort & $25 / 16$ & $24 \% / 18.8 \%$ & NR & $4 \% / 0$ & $12 \% / 12.5 \%$ \\
\hline Lubrano, 2017 [63] & axSpA & Retrospective & $228 / 93$ & NR & MASES 0/1* & NR & NR \\
\hline Kilic, 2017 [64] & axSpA & $\begin{array}{l}\text { Cross-sectional observational } \\
\text { cohort }\end{array}$ & $221 / 139$ & $34 \% / 19 \%$ & NR & $3 \% / 2 \%$ & $16 \% / 7 \%$ \\
\hline Webers, 2016 [48•] & AS & $\begin{array}{l}\text { Prospective observational } \\
\text { cohort }\end{array}$ & $154 / 62$ & $18.2 \% / 18.0 \%$ & MEI $13.5 \% / 18.7 \% *$ & $7.8 \% / 4.9 \%$ & $3.9 \% / 4.9 \%$ \\
\hline Landi, 2016 [49] & $\operatorname{axSpA}$ & Observational cohort & $817 / 255$ & $23.9 \% / 23.4 \%$ & $41.1 \% / 67.9 \% *$ & NR & NR \\
\hline $\begin{array}{l}\text { Shahlaee, } 2015 \\
\quad[50]\end{array}$ & AS & Prospective cohort & $253 / 67$ & $15.8 \% / 13.4 \%$ & $68.8 \% / 82.1 \% *$ & $7.5 \% / 7.5 \%$ & $4.7 \% / 3.0 \%$ \\
\hline Zarco, 2015 [60] & AS & $\begin{array}{l}\text { Prospective observational } \\
\text { cohort }\end{array}$ & $379 / 222$ & $14.0 \% / 13.1 \%$ & NR & $5.0 \% / 5.4 \%$ & $24.8 \% / 32.9 \% *$ \\
\hline $\begin{array}{l}\text { Mitulescu, } 2015 \\
\quad[65]\end{array}$ & $\operatorname{axSpA}$ & Retrospective & $81 / 45$ & $12.3 \% / 2.2 \% *$ & NR & NR & NR \\
\hline $\begin{array}{l}\text { Tournadre, } 2013 \\
\text { [61] }\end{array}$ & axSpA & Prospective cohort & $239 / 236$ & NR & MASES $1.4 / 3.4 *$ & NR & NR \\
\hline $\begin{array}{l}\text { Carvalho, } 2012 \\
\text { [66] }\end{array}$ & AS & Observational cohort & $1090 / 415$ & $19.8 \% / 16.8 \%$ & $\begin{array}{l}\text { Enthesitis } 28 \% / 25 \% \\
\text { MASES } 2.0 / 2.42 *\end{array}$ & NR & $13.8 \% / 29.1 \%$ * \\
\hline Yacoub, 2011 [52] & AS & Cross-sectional & $87 / 43$ & NR & MEI 5.2/7.7* & NR & NR \\
\hline $\begin{array}{l}\text { Attagunduz, } 2010 \\
\text { [55] }\end{array}$ & AS & Cross-sectional & $139 / 96$ & $20.6 \% / 26.2 \%$ & $36.4 \% / 64.8 \% *$ & NR & NR \\
\hline $\begin{array}{l}\text { Braakenburg, } 2008 \\
\text { [67] }\end{array}$ & $\begin{array}{l}\text { HLA-B27 } \\
\text { associated } \\
\text { AAU }\end{array}$ & Retrospective & $96 / 81$ & $54 \% / 46 \%$ & NR & NR & NR \\
\hline
\end{tabular}

$M$ male, $F$ female, $N R$ not reported, MASES Maastricht Ankylosing Spondylitis Enthesitis Score, MEI Mander Enthesitis Index, IBD inflammatory bowel disease, axSpA axial spondyloarthritis, $A S$ ankylosing spondylitis, HLA-B27 human leukocyte antigen B-27, $A A U$ acute anterior uveitis

*Significant gender differences 
in $\mathrm{SpA}$, and more often associated with other diseases, such as sarcoidosis.

Enthesitis is more common and more severe among in female patients $[49,50,52,61,63,66]$. This finding could be an explanation for the same or even higher disease burden in female patients compared to males, despite their slower radiological progression. Three studies, including a systematic review and meta-analysis, indicate that female patients experience more inflammatory bowel disease (IBD) compared to male patients $[60,61,70]$. In addition, there are some studies that showed a higher prevalence of psoriasis in female axSpA patients compared to males $[60,65]$.

Overall, although there are some conflicting results, it seems that female patients more frequently have enthesitis and IBD, whereas male patients may have AAU more frequently.

\section{Disease Activity and Severity}

Disease Activity Scores Female axSpA patients showed a higher disease burden concerning disease activity and pain scores (Table 4). Reported were significantly higher Bath Ankylosing Spondylitis Disease Activity Index (BASDAI) scores in females compared to males, of which the items fatigue, total back pain, and longer duration of morning stiffness showed the largest differences [26••, 27, 30, 48•, 49, 50, 52, $54,61,66]$. Only one study showed higher Bath Ankylosing Spondylitis Functionality (BASFI) scores in female patients, whereas the other studies showed no gender difference [61]. The limited data available considering the AS Disease Activity Score (ASDAS) showed no gender differences $[26 \bullet \bullet, 48 \bullet]$. Studies on sex differences in CRP levels showed significantly higher baseline levels in male patients compared to females [26••, 48•, 50, 61, 63]. Data on ESR levels were inconclusive to identify sex differences.

Quality of Life Female gender corresponded with a significantly lower quality of life (QoL) according to the ASQoL (questionnaire for QoL in AS) compared to male patients in most studies [48•, 49, 50, 66] (Table 4). However, other QoL questionnaires, such as EuroQL and SF-36 scores, showed no (large) differences over time [48•]. Female axSpA patients also showed higher Bath Ankylosing Spondylitis Global scores (BASG) [54, 61, 66], which indicate that female patients experienced worse overall well-being in daily life compared to males. These results are consistent with observations done in rheumatoid arthritis and other autoimmune diseases, where female patients have worse QoL scores compared with males despite equal control of inflammation [74].

Differences in Radiological Progression Overall, most studies were small but showed that men had worse radiological progression compared to women, although one study showed the opposite (Table 5) [61]. Frequently, male sex was indicated as a prognostic factor for worse and more severe radiological progression including development of syndesmophytes, measured with the BASRI-spine and mSASSS scores [73, 77, 80-82, 85]. Additionally, hip involvement seems to be worse in male patients $[68,72]$. However, more extensively research revealed a small nuance in radiological progression. Female patients seem to have higher progression in the cervical spine and males in the lumbar spine, thereby female patients showed slow radiological progression and males fast progression [76]. This slower radiological progression in women probably results in more nr-axSpA diagnoses in female axSpA patients compared to males [86]. Despite the lower radiological progression, the disease burden in female patients is still high. Several studies confirmed that nr-axSpA patients (both male and female) showed the same levels of disease activity, pain, and impaired function as "radiological axSpA" or AS patients [87].

\section{Treatment Response and Drug Adherence}

Overall, treatment efficacy of TNFi is significantly lower in women compared to men with $\operatorname{axSpA}$, and they have a significantly lower drug adherence (Table 6). In most randomized controlled trials, these gender differences in efficacy were not shown due to the relatively low numbers of women included and because most studies were only powered for efficacy of the drug and not to detect gender differences in response. However, if the data of these trials were reanalyzed after stratification for gender, a significantly lower level of response (ASDAS and BASDAI) and treatment adherence in females was found [23, 26••, 27, 28, 30-33, 63, 91] (Table 6). These studies indicate that women with AS have doubled risk at lower drug adherence of TNFi compared with males. In addition, significantly more female patients switched TNFi treatment, which indicate worse treatment adherence in female patients $[90,92]$. This may also imply a weaker treatment response.

Some predictors were associated with a better treatment response, such as the presence of the HLA-B27, absence of enthesitis, short disease duration, and being TNFi naive [33, 92]. Interestingly, these predictors were negatively associated with female gender, because women with AS have a higher prevalence of enthesitis and had a longer delay in diagnosis (Tables 2 and 3). These factors may contribute to the gender differences in TNFi adherence and response.

Currently, gender differences in treatment response are still a dilemma. However, almost no specific studies considering gender and sex differences were performed. A re-analysis of randomized clinical trials, which are powered for efficacy and toxicity between the studied drug (or placebo), and not for sex 


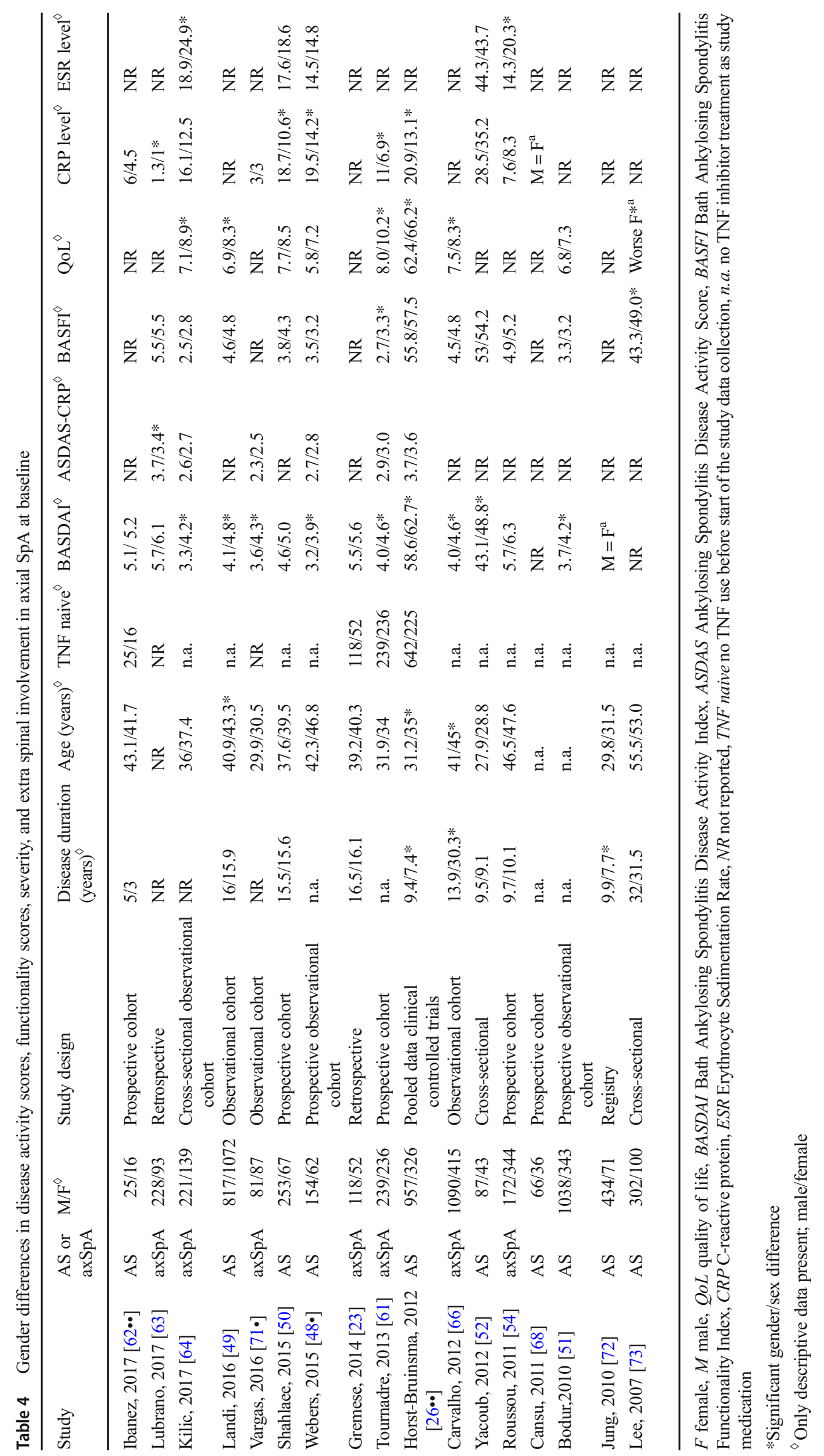




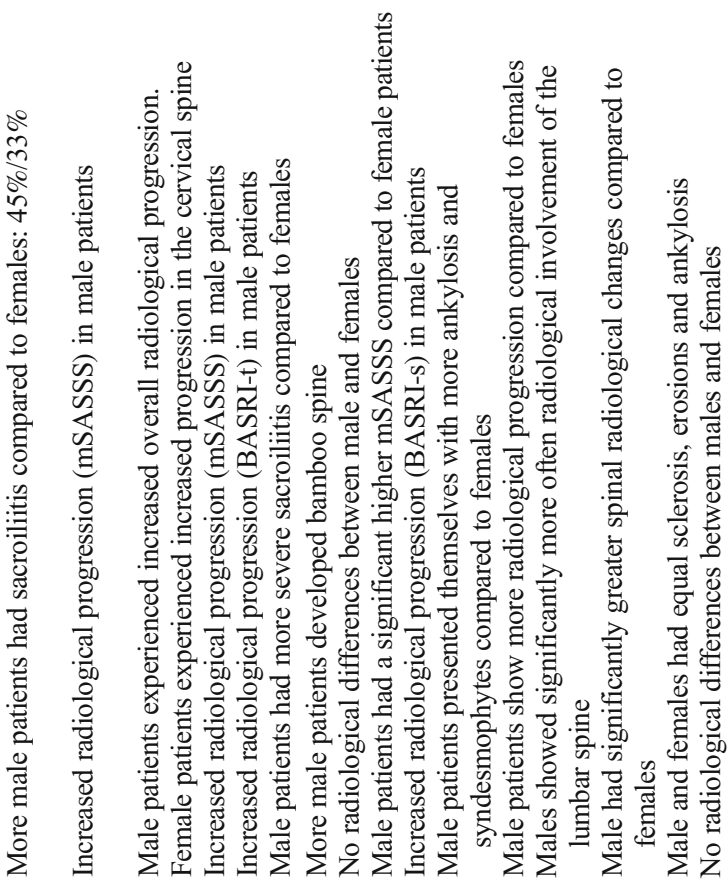

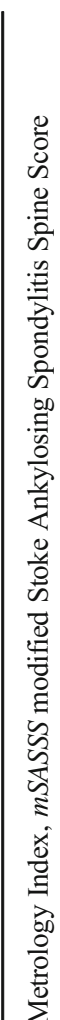

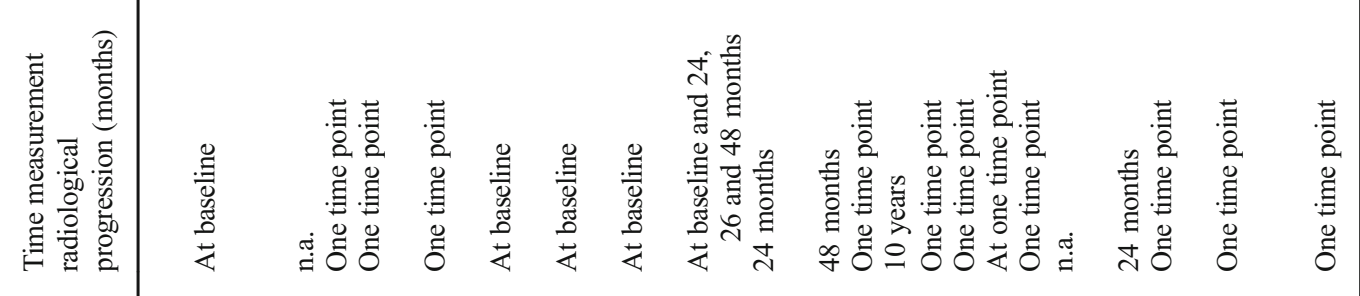

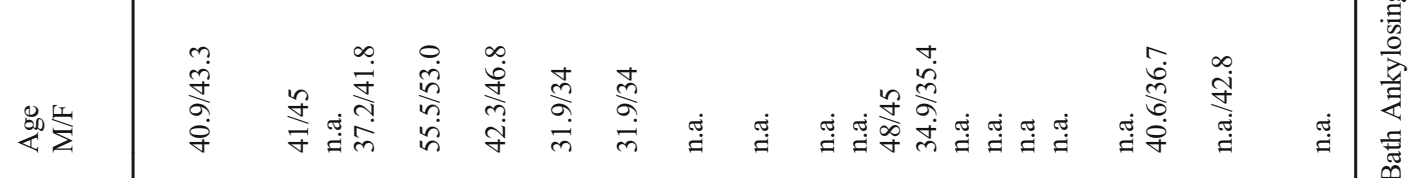

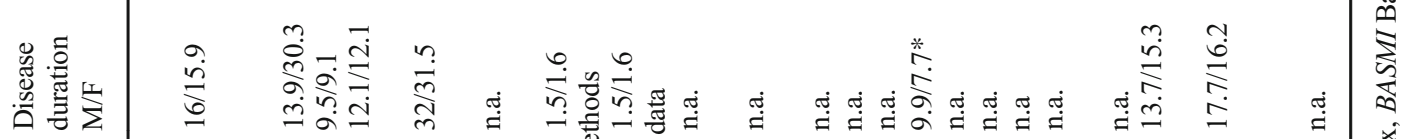

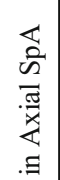

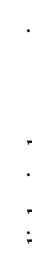

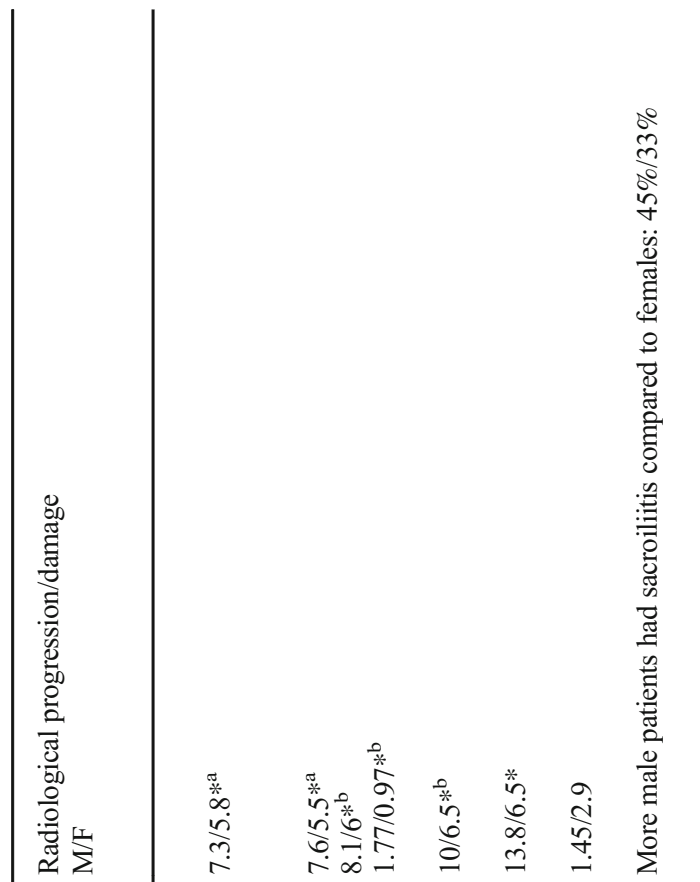

的

0 .

प्य

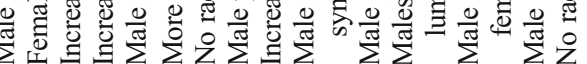


Table 6 Gender differences in TNFi treatment response and adherence

\begin{tabular}{|c|c|c|c|c|c|c|}
\hline Study & AS or axSpA & Study design & $\mathrm{M} / \mathrm{F}$ & Treatment response $\mathrm{M} / \mathrm{F}$ & $\begin{array}{l}\text { TNF naive } \\
\text { population }\end{array}$ & Follow-up period \\
\hline Lubrano, 2017 [63] & axSpA & Retrospective & $228 / 93$ & ASAS40\%: $\uparrow$ response male $*+$ & Yes & Every 3 months \\
\hline Rusman, 2017 [88] & AS & $\begin{array}{l}\text { Prospective observational } \\
\text { cohort }\end{array}$ & $194 / 97$ & $\begin{array}{l}\text { BASDAI50\%: } 62 \% / 43 \% * \\
\text { BASDAI50\%: } 59 \% / 46 \% * \\
\text { ASDAS: } 64.9 \% / 47.6 \% * \\
\text { ASDAS: } 65.9 \% / 46.3 \% *\end{array}$ & Yes & $\begin{array}{l}12 \text { months } \\
24 \text { months } \\
6 \text { months } \\
12 \text { months }\end{array}$ \\
\hline Lorenzin, 2015 [31] & AS & Retrospective & $52 / 18$ & ASAS20: $82.9 \% / 65.7 \%$ & n.a. & 60 months \\
\hline Gremese, 2013 [23] & axSpA & Retrospective & $118 / 52$ & BASDAI50\%: $67.8 \% / 46.2 \% *$ & Yes & 12 months \\
\hline Horst-Bruinsma, 2012 [26••] & AS & $\begin{array}{l}\text { Pooled data clinical } \\
\text { controlled trials }\end{array}$ & $957 / 326$ & ASDAS: $89.4 \% / 68.4 \% *$ & Yes & 12 weeks \\
\hline Paccou, 2012 [32] & AS & Retrospective & $121 / 68$ & BASDAI50\%: $78.5 \% / 21.5 \% *$ & Yes & 3 months \\
\hline Arends, 2011 [28] & AS & $\begin{array}{l}\text { Prospective longitudinal } \\
\text { observational }\end{array}$ & $152 / 68$ & $\begin{array}{l}\text { ASAS20: } \uparrow \text { response Male* } \ddagger \\
\text { ASAS40: } \uparrow \text { response Male } * \ddagger\end{array}$ & Yes & $\begin{array}{l}3 \text { and } 6 \text { months } \\
6 \text { months }\end{array}$ \\
\hline Glintborg, 2010 [27] & AS & Observational cohort & $364 / 239$ & Change in BASDAI: $27 / 22$ & Yes & 6 months \\
\hline Study & AS or axSpA & Study design & $\mathrm{M} / \mathrm{F}$ & Treatment adherence & \multicolumn{2}{|c|}{ Study time period } \\
\hline Rusman, 2016 [89] & AS & Prospective cohort & $74 / 48$ & $\begin{array}{l}\text { Males: } 44.9 \text { months } \\
\text { Females: } 33.4 \text { months }\end{array}$ & \multicolumn{2}{|c|}{ Mean 4.8 years } \\
\hline Horst-Bruinsma, 2012 [26••] & AS & $\begin{array}{l}\text { Pooled data clinical } \\
\text { controlled trials }\end{array}$ & $957 / 326$ & $\downarrow$ Females: HR: 1.5 & \multicolumn{2}{|l|}{12 weeks } \\
\hline Glintborg, 2013 [90] & AS & Observational cohort & $1076 / 360$ & $\uparrow$ Males: HR:1.76 & \multicolumn{2}{|l|}{10 years } \\
\hline Arends, 2011 [28] & AS & $\begin{array}{l}\text { Prospective longitudinal } \\
\text { observational }\end{array}$ & $152 / 68$ & $\downarrow$ Females: HR:0.41 & \multicolumn{2}{|l|}{6 months } \\
\hline Glintborg, 2010 [27] & AS & Observational cohort & $364 / 239$ & $\downarrow$ Females: HR:3.4 & \multicolumn{2}{|l|}{5 years } \\
\hline Kristensen, 2010 [30] & AS & $\begin{array}{l}\text { Prospective observational } \\
\text { cohort }\end{array}$ & $182 / 61$ & $\uparrow$ Males: HR:0.36 & \multicolumn{2}{|l|}{2 years } \\
\hline Pavelka, 2009 [33] & AS & Prospective observational & $238 / 72$ & $\downarrow$ Females: RR: 2.2 & \multicolumn{2}{|l|}{2 years } \\
\hline
\end{tabular}

Treatment adherence $=$ time on $\mathrm{TNFi}$

$A S$ ankylosing spondylitis, axSpA axial spondyloarthritis, ASAS20 ASAS response criteria, ASDAS Ankylosing Spondylitis Disease Activity Score, BASDAI Bath Ankylosing Spondylitis Disease Activity Score, BASDAI50\% response op de BASDAI 50\%, TNF naive no earlier use of TNFi treatment before study, $H R$ hazard ratio

*Significant gender difference

differences, has only been done in three TNFi studies with etanercept, adalimumab, and infliximab, but not for all the other TNFi nor for the interleukin 17 blocker secukinumab $[88,89]$.

Recently, several hypotheses for gender and sex differences in response to TNFi were formulated, such as difference in body composition. Females have, in general, higher fat percentages compared to males, and different gonadal hormones and even different gene expressions compared to male axSpA patients $[1 \bullet \bullet$.

Several studies showed that a higher body mass index (BMI) resulted in a lower TNFi treatment response [23, 71•], of which one of the studies even found a correlation between BMI and the inflammation marker CRP in female axSpA patients [71•]. In addition, other data revealed that there was a significant relationship between female AS patients with high disease activity scores (ASDAS and BASDAI) and a high body fat percentage $(\mathrm{BF} \%)$ or fat mass index (FMI), as contradicting male patients with high disease activity scores had low BF\% and FMI [29]. Overall, women in general have a higher $\mathrm{BF} \%$ compared to males, which might be an explanation for the worse TNFi treatment response in female axSpA patients [62••]. As mentioned previously, male axSpA patients showed a significantly elevated level of TNF $\alpha$ compared to female patients, which might be another possible explanation for a worse TNFi treatment response in female axSpA patients.

\section{Conclusion}

Despite the fact that male axSpA patients has more radiographic damage compared to females, female patients have a higher disease burden due to a longer diagnostic delay, higher disease activity, and a lower efficacy of treatment. Although there is increased recognition, of sex and gender differences in axSpA, this review also demonstrated a persistent lack of comprehensive knowledge about disease manifestations in female patients. Further studies into sex and gender differences in the manifestation of axSpA may result in less underdiagnosis and misdiagnosis, more optimal treatment 
strategies, and decreased overall disease burden in female axSpA patients.

\section{Compliance with Ethical Standards}

Conflict of Interest Prof. van der Horst-Bruinsma reports grants from $\mathrm{UCB}$, grants from MSD, grants from Pfizer, personal fees from BMS, and personal fees from AbbVie, outside the submitted work; Dr. van Vollenhoven reports grants and personal fees from AbbVie, grants and personal fees from BMS, grants and personal fees from GSK, grants and personal fees from Pfizer, grants and personal fees from UCB, personal fees from AstraZeneca, personal fees from Biotest, personal fees from Celgene, personal fees from Janssen, personal fees from Lilly, personal fees from Novartis, outside the submitted work; T. Rusman declare that he have no conflict of interest.

Human and Animal Rights and Informed Consent This article does not contain any studies with human or animal subjects performed by any of the authors.

Open Access This article is distributed under the terms of the Creative Commons Attribution 4.0 International License (http:// creativecommons.org/licenses/by/4.0/), which permits unrestricted use, distribution, and reproduction in any medium, provided you give appropriate credit to the original author(s) and the source, provide a link to the Creative Commons license, and indicate if changes were made.

\section{References}

Papers of particular interest, published recently, have been highlighted as:

- Of importance

•. Of major importance

1.• Tannenbaum C, Day D, Matera A. Age and sex in drug development and testing for adults. Pharmacol Res. 2017;121:83-93. This paper provides an clear overview of the under representation and recognition of gender and sex in general in scientific studies in all stages of drug development: at cellular level, in animal research and in clinical trials, which often results in an underestimation of the potential risks of new drugs in women.

2. Fish EN. The X-files in immunity: sex-based differences predispose immune responses. Nat Rev Immunol. 2008;8(9):737-44.

3. Kouvari M, Yannakoulia M, Souliotis K, Panagiotakos DB. Challenges in sex- and gender-centered prevention and management of cardiovascular disease: implications of genetic, metabolic, and environmental paths. Angiology. 2018;3319718756732.

4. Regitz-Zagrosek V, Seeland U. Sex and gender differences in clinical medicine. Handb Exp Pharmacol. 2012;214:3-22.

5. Rudwaleit M, van der Heijde D, Landewe R, Listing J, Akkoc N, Brandt J, et al. The development of assessment of SpondyloArthritis International Society classification criteria for axial spondyloarthritis (part II): validation and final selection. Ann Rheum Dis. 2009;68(6):777-83.

6. Khan MA, van der Linden SM, Kushner I, Valkenburg HA, Cats A. Spondylitic disease without radiologic evidence of sacroiliitis in relatives of HLA-B27 positive ankylosing spondylitis patients. Arthritis Rheum. 1985;28(1):40-3.

7. Rudwaleit M, van der Heijde D, Landewe R, Akkoc N, Brandt J, Chou CT, et al. The assessment of SpondyloArthritis International Society classification criteria for peripheral spondyloarthritis and for spondyloarthritis in general. Ann Rheum Dis. 2011;70(1):2531.

8. Bennett AN, McGonagle D, O'Connor P, Hensor EM, Sivera F, Coates LC, et al. Severity of baseline magnetic resonance imaging-evident sacroiliitis and HLA-B27 status in early inflammatory back pain predict radiographically evident ankylosing spondylitis at eight years. Arthritis Rheum. 2008;58(11):3413-8.

9. Gong Y, Zheng N, Chen SB, Xiao ZY, Wu MY, Liu Y, et al. Ten years' experience with needle biopsy in the early diagnosis of sacroiliitis. Arthritis Rheum. 2012;64(5):1399-406.

10. West HF. Aetiology of ankylosing spondylitis. Ann Rheum Dis. 1949;8(2):143-8.

11. Polley HF, Slocumb CH. Rheumatoid spondylitis; a study of 1,035 cases. Ann Rheum Dis. 1947;6(2):95-8.

12. Moll JM, Haslock I, Macrae IF, Wright V. Associations between ankylosing spondylitis, psoriatic arthritis, Reiter's disease, the intestinal arthropathies, and Behcet's syndrome. Medicine (Baltimore). 1974;53(5):343-64.

13. Hill HF, Hill AG, Bodmer JG. Clinical diagnosis of ankylosing spondylitis in women and relation to presence of HLA-B27. Ann Rheum Dis. 1976;35(3):267-70.

14. Carbone LD, Cooper C, Michet CJ, Atkinson EJ, O'Fallon WM, Melton LJ 3rd. Ankylosing spondylitis in Rochester, Minnesota, 1935-1989. Is the epidemiology changing? Arthritis Rheum. 1992;35(12):1476-82.

15. Gran JT, Ostensen M, Husby G. A clinical comparison between males and females with ankylosing spondylitis. J Rheumatol. 1985;12(1):126-9.

16. Kennedy LG, Will R, Calin A. Sex ratio in the spondyloarthropathies and its relationship to phenotypic expression, mode of inheritance and age at onset. J Rheumatol. 1993;20(11):1900-4.

17. Masi AT, Wilkins WR. Does male:female sex ratio in ankylosing spondylitis change with age? J Rheumatol. 1996;23(5):947-8.

18. Calin A, Elswood J, Rigg S, Skevington SM. Ankylosing spondylitis - an analytical review of 1500 patients: the changing pattern of disease. J Rheumatol. 1988;15(8):1234-8.

19. Will R, Edmunds L, Elswood J, Calin A. Is there sexual inequality in ankylosing spondylitis? A study of 498 women and 1202 men. J Rheumatol. 1990;17(12):1649-52.

20. Baumberger H, Khan M. Gradual progressive change to equal prevalence of ankylosing spondylitis among males and females in Switzerland: data from the swiss ankylosing spondylitis society (SVMB) [abstract]. Ann Rheum Dis. 2017.

21. van den Berg R, van Gaalen F, van der Helm-van Mil A, Huizinga T, van der Heijde D. Performance of classification criteria for peripheral spondyloarthritis and psoriatic arthritis in the Leiden early arthritis cohort. Ann Rheum Dis. 2012;71(8):1366-9.

22. Sieper J, van der Heijde D. Review: Nonradiographic axial spondyloarthritis: new definition of an old disease? Arthritis Rheum. 2013;65(3):543-51.

23. Gremese E, Bernardi S, Bonazza S, Nowik M, Peluso G, Massara $\mathrm{A}$, et al. Body weight, gender and response to TNF-alpha blockers in axial spondyloarthritis. Rheumatology (Oxford). 2014;53(5): $875-81$.

24. de Winter JJ, van Mens LJ, van der Heijde D, Landewe R, Baeten DL. Prevalence of peripheral and extra-articular disease in ankylosing spondylitis versus non-radiographic axial spondyloarthritis: a meta-analysis. Arthritis Res Ther. 2016;18:196.

25. Sepriano A, Regel A, van der Heijde D, Braun J, Baraliakos X, Landewe R, et al. Efficacy and safety of biological and targetedsynthetic DMARDs: a systematic literature review informing the 2016 update of the ASAS/EULAR recommendations for the management of axial spondyloarthritis. RMD Open. 2017;3(1): e000396.

26.• van der Horst-Bruinsma IE, Zack DJ, Szumski A, Koenig AS. Female patients with ankylosing spondylitis: analysis of the impact 
of gender across treatment studies. Ann Rheum Dis. 2013;72(7): 1221-4. This is one of the few studies that re-analyzed clinical placebo-controlled trials with a TNF inhibitor for gender and found a significant lower treatment response (ASDAS) and adherence in axial spondyloarthritis in women, which did not come out in the separate clinical trials due to the low numbers of included women.

27. Glintborg B, Ostergaard M, Krogh NS, Dreyer L, Kristensen HL, Hetland ML. Predictors of treatment response and drug continuation in 842 patients with ankylosing spondylitis treated with antitumour necrosis factor: results from 8 years' surveillance in the Danish nationwide DANBIO registry. Ann Rheum Dis. 2010;69(11):2002-8.

28. Arends S, Brouwer E, van der Veer E, Groen H, Leijsma MK, Houtman PM, et al. Baseline predictors of response and discontinuation of tumor necrosis factor-alpha blocking therapy in ankylosing spondylitis: a prospective longitudinal observational cohort study. Arthritis Res Ther. 2011;13(3):R94.

29. Ibanez Vodnizza S, Visman IM, van Denderen C, Lems WF, Jaime F, Nurmohamed MT, et al. Muscle wasting in male TNF-alpha blocker naive ankylosing spondylitis patients: a comparison of gender differences in body composition. Rheumatology (Oxford). 2017;56(9):1566-72.

30. Kristensen LE, Karlsson JA, Englund M, Petersson IF, Saxne T, Geborek P. Presence of peripheral arthritis and male sex predicting continuation of anti-tumor necrosis factor therapy in ankylosing spondylitis: an observational prospective cohort study from the South Swedish Arthritis Treatment Group Register. Arthritis Care Res (Hoboken). 2010;62(10):1362-9.

31. Lorenzin M, Ortolan A, Frallonardo P, Oliviero F, Punzi L, Ramonda R. Predictors of response and drug survival in ankylosing spondylitis patients treated with infliximab. BMC Musculoskelet Disord. 2015;16:166.

32. Paccou J, Bacle-Boutry MA, Solau-Gervais E, Bele-Philippe P, Flipo RM. Dosage adjustment of anti-tumor necrosis factor-alpha inhibitor in ankylosing spondylitis is effective in maintaining remission in clinical practice. J Rheumatol. 2012;39(7):1418-23.

33. Pavelka K, Forejtova S, Stolfa J, Chroust K, Buresova L, Mann H, et al. Anti-TNF therapy of ankylosing spondylitis in clinical practice. Results from the Czech national registry ATTRA. Clin Exp Rheumatol. 2009;27(6):958-63.

34. Gracey E, Yao Y, Green B, Qaiyum Z, Baglaenko Y, Lin A, et al. Sexual dimorphism in the Th17 signature of ankylosing spondylitis. Arthritis Rheumatol. 2016;68(3):679-89. This study provides interesting data on differences in the Th17 axis, which plays an important role in the pathogenesis of axial spondyloarthritis, that indicate sex differences at immunological level as possible underlying sex-related differences in the clinical features of ankylosing spondylitis.

35. Huang WN, Tso TK, Kuo YC, Tsay GJ. Distinct impacts of syndesmophyte formation on male and female patients with ankylosing spondylitis. Int J Rheum Dis. 2012;15(2):163-8.

36. Tsui HW, Inman RD, Reveille JD, Tsui FW. Association of a TNAP haplotype with ankylosing spondylitis. Arthritis Rheum. 2007;56(1):234-43.

37. Tsui HW, Inman RD, Paterson AD, Reveille JD, Tsui FW. ANKH variants associated with ankylosing spondylitis: gender differences. Arthritis Res Ther. 2005;7(3):R513-25.

38. Jeong H, Bae EK, Kim H, Eun YH, Kim IY, Kim H, et al. Estrogen attenuates the spondyloarthritis manifestations of the SKG arthritis model. Arthritis Res Ther. 2017;19(1):198.

39. Mahendira D, Thavaneswaran A, Carty A, Haroon N, Anton A, Passalent L, et al. Analysis of the effect of the oral contraceptive pill on clinical outcomes in women with ankylosing spondylitis. J Rheumatol. 2014;41(7):1344-8.
40. Aydin T, Karacan I, Demir SE, Sahin Z. Bone loss in males with ankylosing spondylitis: its relation to sex hormone levels. Clin Endocrinol. 2005;63(4):467-9.

41. Giltay EJ, Popp-Snijders C, van Schaardenburg D, Dekker-Saeys BJ, Gooren LJ, Dijkmans BA. Serum testosterone levels are not elevated in patients with ankylosing spondylitis. J Rheumatol. 1998;25(12):2389-94.

42. Jimenez-Balderas FJ, Tapia-Serrano R, Madero-Cervera JI, Murrieta S, Mintz G. Ovarian function studies in active ankylosing spondylitis in women. Clinical response to estrogen therapy. J Rheumatol. 1990;17(4):497-502.

43. Giltay EJ, van Schaardenburg D, Gooren LJ, Popp-Snijders C, Dijkmans BA. Androgens and ankylosing spondylitis: a role in the pathogenesis? Ann N Y Acad Sci. 1999;876:340-64. discussion 65 .

44. Feldtkeller E, Bruckel J, Khan MA. Scientific contributions of ankylosing spondylitis patient advocacy groups. Curr Opin Rheumatol. 2000;12(4):239-47.

45. Feldtkeller E, Khan MA, van der Heijde D, van der Linden S, Braun J. Age at disease onset and diagnosis delay in HLA-B27 negative vs. positive patients with ankylosing spondylitis. Rheumatol Int. 2003;23(2):61-6.

46. Mogard E, Lindqvist E, Bergman S, Bremander A. Spinal mobility in axial spondyloarthritis: a cross-sectional clinical study. Musculoskeletal Care. 2017;15(1):36-48.

47. Bandinelli F, Salvadorini G, Delle Sedie A, Riente L, Bombardieri S, Matucci-Cerinic M. Impact of gender, work, and clinical presentation on diagnostic delay in Italian patients with primary ankylosing spondylitis. Clin Rheumatol. 2016;35(2):473-8.

48. Webers C, Essers I, Ramiro S, Stolwijk C, Landewe R, van der Heijde D, et al. Gender-attributable differences in outcome of ankylosing spondylitis: long-term results from the Outcome in Ankylosing Spondylitis International Study. Rheumatology (Oxford). 2016;55(3):419-28. A longitudinal follow up study of AS (the OASIS cohort), with a mean follow up of 8 years, shows significant gender differences in several clinical outcome parameters, such as radiological progression and disease activity scores.

49. Landi M, Maldonado-Ficco H, Perez-Alamino R, MaldonadoCocco JA, Citera G, Arturi P, et al. Gender differences among patients with primary ankylosing spondylitis and spondylitis associated with psoriasis and inflammatory bowel disease in an iberoamerican spondyloarthritis cohort. Medicine (Baltimore). 2016;95(51):e5652.

50. Shahlaee A, Mahmoudi M, Nicknam MH, Farhadi E, Fallahi S, Jamshidi AR. Gender differences in Iranian patients with ankylosing spondylitis. Clin Rheumatol. 2015;34(2):285-93.

51. Bodur H, Ataman S, Bugdayci DS, Rezvani A, Nas K, Uzunca K, et al. Description of the registry of patients with ankylosing spondylitis in Turkey: TRASD-IP. Rheumatol Int. 2012;32(1):169-76.

52. Ibn Yacoub Y, Amine B, Laatiris A, Hajjaj-Hassouni N. Gender and disease features in Moroccan patients with ankylosing spondylitis. Clin Rheumatol. 2012;31(2):293-7.

53. Slobodin G, Reyhan I, Avshovich N, Balbir-Gurman A, Boulman N, Elias M, et al. Recently diagnosed axial spondyloarthritis: gender differences and factors related to delay in diagnosis. Clin Rheumatol. 2011;30(8):1075-80.

54. Roussou E, Sultana S. Spondyloarthritis in women: differences in disease onset, clinical presentation, and bath ankylosing spondylitis disease activity and functional indices (BASDAI and BASFI) between men and women with spondyloarthritides. Clin Rheumatol. 2011;30(1):121-7.

55. Atagunduz P, Aydin SZ, Bahadir C, Erer B, Direskeneli H. Determinants of early radiographic progression in ankylosing spondylitis. J Rheumatol. 2010;37(11):2356-61. 
56. Dincer U, Cakar E, Kiralp MZ, Dursun H. Diagnosis delay in patients with ankylosing spondylitis: possible reasons and proposals for new diagnostic criteria. Clin Rheumatol. 2008;27(4):457-62.

57. Reed MD, Dharmage S, Boers A, Martin BJ, Buchanan RR, Schachna L. Ankylosing spondylitis: an Australian experience. Intern Med J. 2008;38(5):321-7.

58. Jovani V, Blasco-Blasco M, Ruiz-Cantero MT, Pascual E. Understanding how the diagnostic delay of spondyloarthritis differs between women and men: a systematic review and metaanalysis. J Rheumatol. 2017;44(2):174-83. A meta-analyses on Spondyloarthritis, including mainly papers on Axial Spondyloarthritis, which clearly demonstrates a significant difference in delay of diagnosis in women of 2.3 years compared to males, despite the same age of onset of complaints.

59. Aloush V, Ablin JN, Reitblat T, Caspi D, Elkayam O. Fibromyalgia in women with ankylosing spondylitis. Rheumatol Int. 2007;27(9): 865-8.

60. Zarco P, Gonzalez CM, Rodriguez de la Serna A, Peiro E, Mateo I, Linares L, et al. Extra-articular disease in patients with spondyloarthritis. Baseline characteristics of the spondyloarthritis cohort of the AQUILES study. Reumatol Clin. 2015;11(2):83-9.

61. Tournadre A, Pereira B, Lhoste A, Dubost JJ, Ristori JM, Claudepierre P, et al. Differences between women and men with recent-onset axial spondyloarthritis: results from a prospective multicenter French cohort. Arthritis Care Res (Hoboken). 2013;65(9): 1482-9.

62.• Ibanez Vodnizza SE, Nurmohamed MT, Visman IM, van Denderen JC, Lems WF, Jaime F, et al. Fat mass lowers the response to tumor necrosis factor-alpha blockers in patients with ankylosing spondylitis. J Rheumatol. 2017;44(9):1355-61. In addition to previous publications, that have shown a relation between high BMI and lower response to TNF inhibitors in general, this is the first study that demonstrates the association between a higher amount of body fat and a worse response on TNF inhibitors (measured by ASDAS-CRP) and female gender.

63. Lubrano E, Perrotta FM, Manara M, D'Angelo S, Addimanda O, Ramonda R, et al. The sex influence on response to tumor necrosis factor-alpha inhibitors and remission in axial spondyloarthritis. J Rheumatol. 2017; https://doi.org/10.3899/jrheum.17666.

64. Kilic G, Kilic E, Ozgocmen S. Is there any gender-specific difference in the cut-off values of ankylosing spondylitis disease activity score in patients with axial spondyloarthritis? Int J Rheum Dis. 2017;20(9):1201-11.

65. Mitulescu TC, Popescu C, Naie A, Predeteanu D, Popescu V, Alexandrescu $\mathrm{C}$, et al. Acute anterior uveitis and other extraarticular manifestations of spondyloarthritis. J Med Life. 2015;8(3):319-25.

66. de Carvalho HM, Bortoluzzo AB, Goncalves CR, da Silva JA, Ximenes AC, Bertolo MB, et al. Gender characterization in a large series of Brazilian patients with spondyloarthritis. Clin Rheumatol. 2012;31(4):687-95.

67. Braakenburg AM, de Valk HW, de Boer J, Rothova A. Human leukocyte antigen-B27-associated uveitis: long-term follow-up and gender differences. Am J Ophthalmol. 2008;145(3):472-9.

68. Cansu DU, Calisir C, Savas Yavas U, Kasifoglu T, Korkmaz C. Predictors of radiographic severity and functional disability in Turkish patients with ankylosing spondylitis. Clin Rheumatol. 2011;30(4):557-62.

69. Zeboulon N, Dougados M, Gossec L. Prevalence and characteristics of uveitis in the spondyloarthropathies: a systematic literature review. Ann Rheum Dis. 2008;67(7):955-9.

70. Stolwijk C, van Tubergen A, Castillo-Ortiz JD, Boonen A. Prevalence of extra-articular manifestations in patients with ankylosing spondylitis: a systematic review and meta-analysis. Ann Rheum Dis. 2015;74(1):65-73.
71. Rubio Vargas R, van den Berg R, van Lunteren M, Ez-Zaitouni Z, Bakker PA, Dagfinrud H, et al. Does body mass index (BMI) influence the ankylosing spondylitis disease activity score in axial spondyloarthritis?: data from the SPACE cohort. RMD Open. 2016;2(1):e000283. In a very early axial spA cohort (SPACE) it was described that BMI only influenced the CRP levels in females, but not in males.

72. Jung YO, Kim I, Kim S, Suh CH, Park HJ, Park W, et al. Clinical and radiographic features of adult-onset ankylosing spondylitis in Korean patients: comparisons between males and females. J Korean Med Sci. 2010;25(4):532-5.

73. Lee W, Reveille JD, Davis JC Jr, Learch TJ, Ward MM, Weisman $\mathrm{MH}$. Are there gender differences in severity of ankylosing spondylitis? Results from the PSOAS cohort. Ann Rheum Dis. 2007;66(5):633-8.

74. Lesuis N, Befrits R, Nyberg F, van Vollenhoven RF. Gender and the treatment of immune-mediated chronic inflammatory diseases: rheumatoid arthritis, inflammatory bowel disease and psoriasis: an observational study. BMC Med. 2012;10:82.

75. Maas F, Spoorenberg A, Brouwer E, Bos R, Efde M, Chaudhry RN, et al. Spinal radiographic progression in patients with ankylosing spondylitis treated with TNF-alpha blocking therapy: a prospective longitudinal observational cohort study. PLoS One. 2015;10(4): e0122693.

76. Baraliakos X, Listing J, von der Recke A, Braun J. The natural course of radiographic progression in ankylosing spondylitis: differences between genders and appearance of characteristic radiographic features. Curr Rheumatol Rep. 2011;13(5):3837.

77. van Tubergen A, Ramiro S, van der Heijde D, Dougados M, Mielants H, Landewe R. Development of new syndesmophytes and bridges in ankylosing spondylitis and their predictors: a longitudinal study. Ann Rheum Dis. 2012;71(4):518-23.

78. Jang JH, Ward MM, Rucker AN, Reveille JD, Davis JC Jr, Weisman MH, et al. Ankylosing spondylitis: patterns of radiographic involvement - a re-examination of accepted principles in a cohort of 769 patients. Radiology. 2011;258(1):192-8.

79. Aggarwal R, Malaviya AN. Clinical characteristics of patients with ankylosing spondylitis in India. Clin Rheumatol. 2009;28(10): 1199-205.

80. Rudwaleit M, Haibel H, Baraliakos X, Listing J, Marker-Hermann E, Zeidler H, et al. The early disease stage in axial spondylarthritis: results from the German Spondyloarthritis Inception Cohort. Arthritis Rheum. 2009;60(3):717-27.

81. Ward MM, Hendrey MR, Malley JD, Learch TJ, Davis JC Jr, Reveille JD, et al. Clinical and immunogenetic prognostic factors for radiographic severity in ankylosing spondylitis. Arthritis Rheum. 2009;61(7):859-66.

82. Boonen A, vander Cruyssen B, de Vlam K, Steinfeld S, Ribbens C, Lenaerts J, et al. Spinal radiographic changes in ankylosing spondylitis: association with clinical characteristics and functional outcome. J Rheumatol. 2009;36(6):1249-55.

83. Calin A, Mackay K, Santos H, Brophy S. A new dimension to outcome: application of the Bath Ankylosing Spondylitis Radiology Index. J Rheumatol. 1999;26(4):988-92.

84. Kidd B, Mullee M, Frank A, Cawley M. Disease expression of ankylosing spondylitis in males and females. J Rheumatol. 1988;15(9):1407-9.

85. Ramiro S, van der Heijde D, van Tubergen A, Stolwijk C, Dougados M, van den Bosch F, et al. Higher disease activity leads to more structural damage in the spine in ankylosing spondylitis: 12-year longitudinal data from the OASIS cohort. Ann Rheum Dis. 2014;73(8):1455-61.

86. Montilla C, Diaz-Alvarez A, Calero-Paniagua I, Collantes-Estevez E, Font $\mathrm{P}$, Almodovar R, et al. Ankylosing spondylitis without axial 
progression: analysis of associated factors. J Rheumatol. 2014;41(12):2409-12.

87. Boonen A, Sieper J, van der Heijde D, Dougados M, Bukowski JF, Valluri S, et al. The burden of non-radiographic axial spondyloarthritis. Semin Arthritis Rheum. 2015;44(5):556-62.

88. Rusman T, Nurmohamed MT, van Denderen JC, Visman I, van der Horst-Bruinsma IE. Female gender is associated with a poorer response to tnf inhibitors in ankylosing spondylitis [abstract]. Ann Rheum Dis. 2017;

89. Rusman T, ten Wolde S, Euser SM, van der Ploeg T, van Hall O, Van der Horst - Bruinsma IE. Gender differences in retention rate of tumor necrosis factor alpha inhibitor treatment in ankylosing spondylitis: a retrospective cohort study in daily practice [in press]. Int $\mathrm{J}$ Rheum Dis. 2018 Apr;21(4):836-42 https://doi.org/10.1111/1756$185 X .13271$
90. Glintborg B, Ostergaard M, Krogh NS, Tarp U, Manilo N, Loft AG, et al. Clinical response, drug survival and predictors thereof in 432 ankylosing spondylitis patients after switching tumour necrosis factor alpha inhibitor therapy: results from the Danish nationwide DANBIO registry. Ann Rheum Dis. 2013;72(7): 1149-55.

91. Gulfe A, Kapetanovic MC, Kristensen LE. Efficacy and drug survival of anti-tumour necrosis factor-alpha therapies in patients with non-radiographic axial spondyloarthritis: an observational cohort study from Southern Sweden. Scand J Rheumatol. 2014;43(6): 493-7.

92. Deodhar A, Yu D. Switching tumor necrosis factor inhibitors in the treatment of axial spondyloarthritis. Semin Arthritis Rheum. 2017;47:343-50. 